\title{
PENGARUH KOMPETENSI DAN INDEPENDENSI AUDITOR TERHADAP KUALITAS AUDIT DENGAN ETIKA AUDITOR SEBAGAI VARIABEL MODERATING PADA KANTOR AKUNTAN PUBLIK DI KOTA MEDAN
}

\section{EFFECT OF AUDITOR COMPETENCE AND INDEPENDENCE ON AUDIT QUALITY WITH AUDITOR ETHICS AS A MODERATING VARIABLE IN PUBLIC ACCOUNTING FIRMS IN MEDAN CITY}

\author{
Dokman Marulitua Situmorang ${ }^{1}$, Erlina ${ }^{2}$, Bambang Satriawan ${ }^{3}$ \\ ${ }^{1}$ Sekolah Tinggi Ilmu Manajemen Shanti Bhuana - Kalimantan Barat \\ 2Universitas Sumatera Utara - Sumatera Utara \\ 3Universitas Batam - Batam, Kepulauan Riau \\ Email : dokman@shantibhuana.ac.id
}

\begin{abstract}
ABSTRAK
Tujuan penelitian ini adalah untuk mengetahui pengaruh hubungan antara Kompetensi terhadap kualitas audit, Independensi terhadap kualitas audit, kompetensi dan independensi terhadap kualitas audit serta mengetahui apakah etika auditor sebagai variabel moderasi mampu memoderasi kompetensi terhadap kualitas audit, independensi terhadap kualitas audit. Jumlah sampel yang digunakan sebanyak 60 auditor yang terdiri dari 10 kantor akuntan public yang ada dikota medan. Untuk alat analisis dengan mengunakan uji asumsi klasik dan uji residual. Berdasarkan hasil penelitian, maka dapat diambil kesimpulan bahwa hubungan antara kompetensi terhadap kualitas audit berpengaruh positif, independensi berpengaruh positif terhadap kualitas audit, demikian juga secara bersamaan kompetensi, independensi berpengaruh positif terhadap kualitas audit. Sedangkan hasil moderasi, bahwa etika auditor bukanlah variabel moderasi yang mampu mempengaruhi kompetensi terhadap kualitas audit dan independensi terhadap kualitas audit.
\end{abstract}

Kata Kunci : Kompetensi, Independensi, Etika auditor, Kualitas audit

\begin{abstract}
The purpose of this study was to determine the effect of the relationship between Competence on audit quality, Independence on audit quality, competence and independence on audit quality and find out whether auditor ethics as a moderating variable is able to moderate competence on audit quality, independence of audit quality. The number of samples used was 60 auditors consisting of 10 public accounting firms in the city of Medan. For analysis tools using the classic assumption test and residual test. Based on the results of the study, it can be concluded that the relationship between competence on audit quality has a positive effect, independence has a positive effect on audit quality, and simultaneously competence, independence has a positive effect on audit quality. While the moderation results, that auditor ethics is not a moderating variable that is able to influence competence on audit quality and independence of audit quality.
\end{abstract}

Keywords: Competence, Independence, Auditor ethics, Audit quality

Hal. 1 


\section{PENDAHULUAN}

Informasi keuangan tersebut disajikan oleh manajemen kepada masyarakat keuangan untuk memungkinkan masyarakat keuangan menilai pertanggungjawaban keuangan manajemen dan untuk menilai kemampuan perusahaan dalam menghasilkan kembalian investasi (return on investment) dan posisi keuangan perusahaan. Namun bagi masyarakat keuangan, laporan keuangan yang disajikan oleh manajemen mengandung kemungkinan adanya pengaruh kepentingan pribadi manajemen dalam menyajikan informasi hasil usaha dan posisi keuangan yang menguntungkan bagi mereka dan keteledoran serta ketidakjujuran yang dilakukan oleh manajemen dalam penyusunan laporan keuangan tersebut. Ada pun identifikasi masalah adalah keuangan perusahaan merupakan hal yang vital atau yang penting dalam sebuah perusahaan, bagaimana perusahaan berjalan jika kondisi keuangannya tidak baik demikian juga jika kondisi keuangannya baik.

Dengan demikian laporan keuangan dari sebuah perusahaan sangatlah penting bagi kelangsungan berjalannya sebuah perusahaan, laporan keuangan yang baik maka menghasilkan persepsi atau pandangan yang baik juga dari pihak-pihak terkait juga baik itu yang ada di dalam perusahaan atau pun yang ada diluar perusahaan. Maka dengan demikian, dalam hal ini pihak yang melakukan dan memberikan persepsi tentang laporan keuangan sangat dituntut memiliki kualitas audit yang baik. Maka pihak KAP sebagai pihak pemeriksa dan yang memberikan opini, harus memiliki Kompetensi, Independensi dan Etika yang baik juga sehingga menghasilkan Kualitas Audit yang baik. Sedangkan batasan masalah adalah Untuk memperjelas pokok masalah penelitian ini, maka lingkup penelitian ini dibatasin pada auditor di kantor akuntan publik yang ada di kota Medan baik yang senior dan auditor junior yang telah pernah melakukan pemeriksaan.

Penelitian ini menggali persepsi auditor yang ada di kantor akuntan publik yang ada di kota Medan mengenai pengaruh kompetensi, independensi dan etika auditor terhadap kualitas audit. Rumusan masalah adalah penelitian ini dilakukan dengan tujuan untuk mengetahui pandangan auditor yang ada di kantor akuntan publik di kota Medan. Ada pun pengaruh yang mempengaruhui kualitas audit faktor-faktor yang dipelajari dalam penelitian ini merupakan penjabaran dari konsep kompetensi dan independensi auditor akuntan publik.

Kompetensi dijabarkan menjadi faktor pengalaman dan pengetahuan, sedangkan independensi dijabarkan menjadi faktor ketidak terikatan terhadap satu pihak, serta adanya tekanan dari pihak lain. Masalah yang ingin dijawab melalui penelitian ini adalah: 1). Apakah kompetensi dari pada auditor berpengaruh terhadap kualitas audit. 2). Apakah independensi dari pada auditor berpengaruh terhadap kualitas audit. 3). Apakah kompetensi dan independensi auditor akuntan publik berpengaruh terhadap kualitas audit. 4). Apakah Etika auditor dapat memoderasi pengaruh hubungan Kompetensi terhadap kualitas audit. 5). Apakah Etika auditor dapat memoderasi pengaruh hubungan Independensi terhadap kualitas audit. Tujuan penelitian ini adalah sebagai berikut: 1). Untuk mengetahui apakah kompetensi auditor berpengaruh terhadap kualitas audit. 2). Untuk mengetahui apakah independensi auditor berpengaruh terhadap kualitas audit. 3). Untuk mengetahui apakah kompetensi dan independensi auditor berpengaruh terhadap kualitas audit. 4). Untuk mengetahui apakah Etika Auditor sebagai variabel moderating berpengaruh terhadap kualitas audit. Penelitian dalam bidang kualitas audit masih sedikit. Untuk itu diharapkan penelitian ini memberi manfaat untuk. Sebagai bahan masukan bagi pihak-pihak yang terkait, sehingga dapat meningkatkan kualitas audit yang dilaksanakan oleh auditor yang ada di kantor akuntan publik, terutama bagi auditor yang ada di kota medan. 


\section{LANDASAN TEORI}

\section{Kompetensi}

Seorang anggota yang menerima suatu perjanjian profesional berarti bahwa ia mempunyai keahlian yang diperlukan untuk menyelesaikan suatu perjanjian sesuai dengan norma profesional, mempergunakan pengetahuan dan kemahirannya dengan keseksamaan dan ketekunan sebagaimana mestinya akan tetapi ia tidak memikul suatu tanggung jawab ata kemutlakan pengetahuan atau pertimbangan.

Kemahiran atau kecakapan dalam praktek akuntansi publik sudah mencakup persyaratan teknis seorang anggota beserta stafnya serta kemampuannya mengawasi dan menilai kualitas pekerjaan yang dilaksanakan. Kemahiran atau kecapakan tersebut berkaitan dengan pengetahuan tentang norma profesi, bagaimana cara dalam menyelesaikan masalah teknis yang bersangkutan, serta berkaitan dengan kemampuan mempergunakan pertimbangan yang sehat dalam usaha menerapkan pengetahuan tersebut dalam masing-masing perjanjian.

Anggota boleh jadi sudah mempunyai pengetahuan yang diperlukan untuk menyelesaikan suatu perjanjian sebelum mengadakan suatu perjanjian tersebut. Bagaimanapun juga, dalam berbagai kasus, penelitian atau konsultasi tambahan dengan pihak lainnya kememungkinan diperlukan selama berlangsungnya perjanjian. Biasanya hal ini tidak menggambarkan suatu kekurangcakapan, akan tetapi merupakan suatu bagian yang normal dari kebijaksanaan profesional terhadap suatu perjanjian.

\section{Independensi}

Dalam melaksanakan audit untuk sampai pada suatu pernyataan pendapat, auditor harus senantiasa bertindak sebagai seorang ahli dalam bidang akuntansi dan auditing. Pencapaian keahlian tersebut dimulai dengan pendidikan formalnya, yang diperluas melalui dengan pengalaman-pengalaman selanjutnya dalam praktik audit. Untuk memenuhui persyaratan sebagai seorang profesional, auditor harus menjalani pelatihan teknis yang cukup. Pelatihan ini harus secara memadai mencakup aspek teknis maupun pendidikan umum. Asisten junior, yang baru masuk ke dalam karir auditing harus memperoleh pengalaman profesionalnya dengan mendapatkan suvervisi yang memadai dan review atas pekerjaanya dari atasannya yang lebih berpengalaman. Sifat dan luasnya suvervisi dan review terhadap hasil pekerjaan tersebut harus meliputi keanekaragaman praktik yang luas. Auditor independen yang memikul tanggung jawab akhir atas suatu perikatan, harus menggunakan pertimbangan matang dalam setiap tahap pelaksanaan supervisi dan dalam review terhadap hasil pekerjaan dan pertimbanganpertimbangan yang dibuat asistennya. Pada gilirannya, para asisten tersebut harus juga memenuhi tanggung jawabnya menurut tingkat dan fungsi pekerjaan mereka masing-masing.

\section{Etika Auditor}

Etika secara garis besar dapat didefinisikan sebagai serangkaian prinsip atau nilai-nilai moral. Setiap orang memiliki rangkaian nilai tersebut, walaupun kita memperhatikan atau tidak memperhatikannnya secara eksplisit. Banyak ahli-ahli mendefinisikan rangkai prinsip dan nilai moral ini dalam berbagai cara. Contoh pelaksanaannya adalah peraturan perundang-undangan, doktrin agama, kode etik bisnis bagi beragam kelompok profesi seperti akuntan publik, serta kode etik dalam berbagai organisasi individual.

Merupakan hal yang umum bagi masyrakat untuk memilah-milah prinsip-prinsip dan nilai moral mereka serta kepentingan relatif prinsip tersebut bagi mereka. Perbedaan-perbedaan ini merefleksikan pengalaman hidup, kesuksesan dan kegagalan yang dialami, serta beragam pengaruh dari orang tua, para guru dan teman.

Hal. 3 
Perilaku beretika wajib hukumnya supaya masyarakat dapat berjalan secara teratur. Kita dapat beragumentasi bahwa etika adalah sejenis perekat yang dapat mengikat erat masyarakat. Seandainya apa yang terjadi jika kita tidak memiliki kepercayaan bahwa orang-orang disekitar kita telah berlaku jujur, mustahil tercapai komunikasi efektif, jika orang tua, para guru, para pemilik perusahaan, saudara kita, para rekan kerja, serta teman-teman kita selalu berkata bohong.

Kebutuhan etika dalam masyarakat sangat mendesak sehingga lazim memasukkan nilainilai etika ini ke dalam undang-undang atau peraturan yang berlaku, sebagian besar masyarakat mendefinisikan perilaku tidak etis sebagai tindakan yang mereka percayai yang merupakan tindakan tepat dan tindakan tepat dilakukan dalam situasi tertentu. Masing-masing dari kita memutuskan bagi kita sendiri, seperti apakah yang kita anggap sebagai perilaku yang tidak etis tersebut, baik bagi kita maupun bagi pihak lainnya. Merupakan suatu hal yang penting untuk dipahami apakah yang menyebabkan suatu tindakan tertentu yang dilakukan sesorang, kita anggap sebagai suatu tindakan yang tidak etis. Dilema etika merupakan situasi yang dihadapi oleh seseorang dimana ia harus membuat keputusan tentang perilaku seperti apa yang tepat untuk dilakukannya.

\section{Kualitas Audit}

Kualitas audit didefinisikan sebagai probabilitas sebagai auditor akan baik dan benar menemukan kesalahan material, keliru atau kelalaian dalam laporan keuangan klien ( De Angelo 1981, dalam Kusharyanti 2009 ).

Probabilitas auditor untuk melaporkan penyelewengan yang terjadi dalam sistem akuntansi klien tergantung pada independensi auditor, seorang auditor dituntut untuk menghasilkan kualitas pekerjaan yang tinggi, karena auditor mempunyai tanggung jawab yang besar terhadap pihakpihak yang berkepentingan terhadapa laporan keuangan perusahaan termasuk masyarakat (Ermayanti, 2009 dalam Sari, 2011) lebih lanjut dikatakan tidak hanya bergantung pada klien saja, auditor pihak yang mempunyai kualifikasi untuk memeriksa dan menguji apakah laporan keuangan telah disajikan secara wajar sesuai dengan prinsip akuntansi yang berlaku.

Audit merupakan suatu proses untuk menguranggi ketidakselarasan informasi yang terdapat antara manajer dan para pemegang saham dan kreditur dengan mengunakan pihak luar untuk memberikan pengesahan terhadap laporan keuangan yang diaudit. Para pengguna laporan keuangan terutama para pemegang saham akan mengambil keputusan berdasarkan pada laporan yang telah dibuat oleh auditor mengenai pengesahan laporan keuangan di dalam sebuah perusahaan.

Goldman dan Barlev (1974) dalam Mutia (2004) menyatakan bahwa laporan auditor mengandung kepentingan tiga kelompok, yaitu : (1) manajer perusahaan yang diaudit, (2) pemegang saham yang diaudit, (3) pihak ke tiga atau pihak luar seperti calon investor, kreditor dan suplier. Masing-masing kepentingan ini merupakan sumber gangguan yang akan memberikan tekanan pada auditor untuk menghasilkan laporan keuangan yang mungkin tidak sesuai dengan standar profesi. Dan dalam hal ini akan berpengaruh terhadap kualitas audit yang dilakukan oleh pihak Auditor. 


\section{Pengembangan Hipotesis}

\section{Pengaruh Kompetensi terhadap Kualitas Audit}

Penelitian yang dilakukan Hamilton da Wright (1982) dalam Kusharyanti (2003) menemukan bahwa auditor yang berpengalaman mempunyai pemahaman yang lebih baik. Mereka juga lebih mampu memberikan penjelasan yang masuk akal atas kesalahan-kesalahan dalam laporan keuangan dan dapat mengelompokkan kesalahan berdasarkan pada tujuan audit dan struktur dari sistem akuntansi yang mendasari (Libby et, AL. 1985 dalam Kusharyanti 2003).

Auditor yang berpendidikan tinggi akan memempunyai pandangan yang lebih luas mengenai berbagai hal. Auditor akan semakin mempunyai banyak pengetahuan mengenai bidang yang digelutinya, sehingga dapat mengetahui berbagai masalah secara lebih mendalam. Selain itu dengan ilmu pengetahuan yang cukup luas, auditor akan lebih mudah dalam mengikuti perkembangan yang semakin kompleks membutuhkan specktrum yang luas mengenai keahlian, pengetahuan dan pengalaman (Meinhard et, al, 1987 dalam Harhinto 2004).

\section{H1 : Kompetensi Berpengaruh terhadap Kualitas Audit}

\section{Pengaruh Independensi terhadapa Kualitas Audit}

Independensi auditor ternyata berhubungan juga dengan telaah yang dilakukan rekan auditor (peer review). Peneliti yang membahas tentang telaah rekan auditor lain dilakukan Austin dan Langston (1981). Peneliti ini ingin menggali dampak telaah dari rekan auditor terhadap pengendalian kualitas dan kinerja yang dilakukan oleh akuntan. Faktor pengendalian kualitas dan kinerja yang dipelajari adalah pengendalian kualitas, self regulation, dan efektivitas cost. Sampel penelitian ini adalah 133 orang akuntan dan 63 orang non-akuntan. Hasil penelitian ini menunjukkan $75 \%$ dari responden akuntan setuju bahwa telaah dari rekan auditor merupakan media yang bermanfaat untuk meningkatkan independensi auditor. Enam puluh lima persen (65) dari responden akuntan dan $70 \%$ dari responden non-akuntan setuju bahwa telaah dari rekan auditor merupakan media yang layak untuk disajikan self-regulation. Faktor efektivitas cost menunjukkan hasil sebaliknya. Ternyata $67 \%$ responden akuntan tidak setuju bahwa telaah dari rekan auditor dapat membuat cost lebih efektif, karena telaah dari rekan auditor tidak menurunkan tingkat litigasi terhadap auditor.

Malone dan Roberts (1996) melakukan penelitian tentang faktor-faktor yang berhubungan dengan menurunnya perilaku kualitas audit. Penelitian yang melibatkan 257 orang auditor dari firma auditor besar dan kecil ini mempelajari faktor-faktor (1) karakteristik personalitas auditor; (2) karakteristik profesional auditor; (3) pengendalian kualitas dan prosedur telaah dari firma auditor; (4) struktur firma auditor; dan (5) persepsi auditor mengenai tekanan anggaran waktu. Hasil penelitian ini menjelaskan bahwa semakin kuat pengendalian kualitas dan prosedur telaah dari firma auditor dan semakin kuat anggapan auditor mengenai hukuman jika melanggar aturan kualitas audit maka penurunan perilaku kualitas audit akan semakin menurun.

\section{H2 : Independensi Berpengaruh terhadapa Kualitas Audit}

\section{Pengaruh Etika Auditor terhadap Kualitas Audit}

Penelitian yang dilakukan oleh Maryani dan Ludigdo (2001) dalam Alim, dkk (2007) bertujuan untuk mengetahui faktor-faktor yang dianggap mempengaruhui sikap dan perilaku etis akuntan serta faktor yang dianggap paling dominan pengaruhnya terhadap sikap dan perilaku tidak etis akuntan. Hasil yang diperoleh dari kuesioner yang tertutup menunjukkan bahwa terdapat sepuluh faktor yang dianggap oleh sebagian besar akuntan mempengaruhi sikap dan perilaku mereka. Sepuluh faktor tersebut adalah religiusitas, pendidikan, organisasional, emotional quotient, lingkungan keluarga, pengalaman hidup, imbalan yang diterima, hukum dan 
posisi atau kedudukan. Sedangkan hasil yang diperoleh dari kuesioner terbuka menunjukkan bahwa terdapat 24 faktor tambahan yang juga dianggap berpengaruh terhadap sikap dan perilaku etis akuntan dimana faktor regiulitas tetap merupakan faktor yang dominan.

H3 : Etika Auditor Berpengaruh terhadap Kualitas Audit

\section{METODOLOGI PENELITIAN}

\section{Jenis Penelitian}

Jenis penelitian ini dapat dikatakan sebagai penelitian kausal-komparatif yaitu tipe penelitian dengan karakteristik masalah berupa sebab akibat antara 2 variabel atau lebih. untuk melihat hubungan beberapa variabel yang belum pasti, Umar (2008) menyebutkan desain kausal berguna untuk menganalisis bagaimana suatu variabel mempengaruhi variabel lain.

\section{Lokasi dan Waktu Penelitian}

Penelitian dilakukan di beberapa Kantor Akuntan Publik yang ada dikota Medan.

\section{Defenisi Variabel}

Kompetensi (X1)

Kompetensi adalah pengalaman pemeriksa dalam tingkat pendidikan, baik pendidikan formal maupun informal yang diukur dari banyaknya pendidikan yang dilalui pemeriksa (auditor). Kompetensi dalam pengaudit merupakan pengetahuan, keahlian dan pengalaman yang dibuthkan auditor untuk dapat melakukan audit secara objektif, cermat dan seksama. Peneliti menggunakan dua dimensi kompetensi dari Murtanto dalam (Mayangsari 2003) yaitu pengalaman dan pengetahuan. Dimana dalam hal ini kompetensi merupakan variabel Independen.

Independensi (X2)

Independen adalah sebuah kode etik, tekat dan prinsip dari seorang auditor dalam menjalankan atau melakukan sebuah audit terhadap laporan keuangan yang diberikan atau yang dipercayakan oleh sebuah perusahaan untuk di periksa sesuai dengan prinsip akuntansi yang berlaku, dengan tidak di intervensi atau dipengaruhui oleh pihak lain atau pihak ke tiga sehingga mengubah hasil audit dari yang sebenarnya.

\section{Etika Auditor (Variabel Moderating)}

Yang merupakan moderating variabel adalah etika auditor dimana sifat dan tingkah laku dari auditor dalam melaksanakan audit terhadap laporan keuangan yang ada. Etika merupakan nilai benar dan salah yang dianut oleh satu golongan atau masyarakat. Prinsip-prinsip yang berhubungan dengan karakteristik nilai-nilai sebagian besar yang dihubungkan dengan perilaku etis, integritas mematuhui janji, loyalitas, keadilan, kepedulian kepada orang lain, menghargai orang lain, dan menjadi warga yang bertanggungjawab (Firdaus, 2005).

Kualitas Audit (Y)

Yang merupakan dependen variabel adalah kualitas audit dimana hasil audit yang diperiksa oleh auditor sehingga menghasilkan sebuah keputusan atau pandangan yang sesuai dengan kaida atau prinsip-prinsip akuntansi yang berlaku. Adanya kesalahan dan ketidakberesan dalam data dan bukti yang mereka periksa, hal ini dapat di ukur berdasarkan persepsi mereka tentang 
kemampuan mereka dalam mendeteksi adanya kesalahan dalam pemeriksaan yang mereka periksa.

\section{Metode Analisis Data}

Pengujian Reliabilitas dan Validitas Data

Uji validitas dilakukan dengan melihat nilai $r$ hitung dibandingkan dengan nilai $r$ table. Jika $r$ hitung lebih besar dari $r$ table, maka item pertanyaan tersebut dinyatakan valid.

Pengujian reliabilitas dilakukan untuk menguji kestabilan dan konsistensi instrument dalam mengukur konsep. Selain itu, pengujian reliabilitas dilakukan untuk membantu menetapkan kesesuaian pengukur. Pengujian reliabilitas setiap variabel dilakukan dengan teknik Cronbach alpha. Teknik ini merupakan pengujian yang paling umum dilakukan pada pengujian reliabilitas inter item, yaitu menggunakan item-item pertanyaan yang berskala multipoint (Sekaran, 1992). Suatu instrument dikatakan reliable jika memiliki nilai cronbach alpha lebih besar dari 0,5 (Nunnally, 1967).

Pengujian Asumsi Klasik

Pengujian Normalitas

Setelah data diuji validitas dan reliabilitas, maka data tersebut diuji normalitasnya. Uji normalitas perlu dilakukan untuk menentukan alat statistik yang dilakukan, Jika data yang diperoleh itu terdistribusi normal dan variansinya sama, maka pengujian hipotesis dilakukan dengan alat statistik parametrik. Jika data yang diperoleh itu tidak terdistribusi normal dan/atau variansinya tidak sama, maka pengujian hipotesis dilakukan dengan alat statistik nonparametrik.

Pengujian normalitas data dilakukan dengan melihat grafik penyebaran data dan uji Kolmogorov-Smirnov (uji K-S). Jika tingkat signifikansinya lebih besar dari 0,05, maka data itu terdistribusi normal.

Uji Heterokedastisitas

Tujuan dari pengujian ini adalah untuk menguji apakah dalam sebuah model regresi, terjadi ketidaksamaan varians dari residual dari satu pengamatan ke pengamatan yang lain. Jika varians dari residual dari suatu pengamatan ke pengamatan lainnya tetap, maka disebut Homoskedastisitas. Dan jika varians berbeda, maka disebut heteroskedastisitas. Model regresi yang baik adalah tidak terjadi heteroskedastisitas. Uji heterokedastisitas dilakukan dengan melihat melihat grafik.

Model Penelitian

Berdasarkan hipotesis yang diajukan, maka model penelitian dapat dibuat sebagai berikut:

Model 1: $Y=a+\beta 1 X 1+\beta 1 X 2+e$

Model 2: X3 $=a+\beta 1 X 1+\beta 1 X 1+e$

Model 3: $\mathrm{e}=\mathrm{a}+\beta 1 \mathrm{y}$

Keterangan:

$$
\begin{array}{ll}
\text { X1 } & =\text { Kompetensi } \\
\text { X2 } & =\text { Independensi } \\
\text { X3 } & =\text { Etika Audit }
\end{array}
$$


Y $\quad=$ Kualitas Audit

\section{Pengujian Hipotesis}

Hipotesis 1 dan 2 diuji dengan menggunakan analisa regresi sederhana karena masingmasing model penelitian hanya memiliki satu variabel independen. Pengujian hipotesis ditujukan untuk menguji ada tidaknya pengaruh dari varibel bebas terhadap variabel dependen. Pengujian hipotesis dengan menggunakan Uji t.

Pengujian $\mathrm{t}$ bisa dilakukan dengan dua cara yaitu dengan melihat tingkat signifikansi atau dengan membandingkan $t$ hitung dengan $t$ tabel. Pengujian dengan tingkat signifikansi dilakukan dengan ketentuan yaitu apabila hasil signifikansi pada tabel ANOVA $<$ a 0,05 , maka $\mathrm{HO}$ ditolak (berpengaruh), sementara sebaliknya apabila tingkat signifikansi pada tabel ANOVA $>$ a 0,05, maka $\mathrm{H} 0$ diterima (tidak berpengaruh).

Pengujian dengan membandingkan $t$ hitung dengan $t$ tabel dilakukan dengan ketentuan yaitu apabila $t$ hitung $>t$ tabel $(a, 0,05)$ maka $\mathrm{HO}$ ditolak (berpengaruh), sementara sebaliknya apabila $t$ hitung $<t$ tabel $(a \quad 0,05)$ maka $\mathrm{HO}$ diterima (tidak berpengaruh). Adapun $t$ tabel dicari dengan memperhatikan tingkat kepercayaan (a) dan derajat bebas (degree of freedom).

Uji Residual

Uji ini digunakan untuk menguji pengaruh deviasi (penyimpangan) dari suatu model. Fokusnya untuk melihat ketidak cocokan yang dihasilkan dari deviasi hubungan linier antar variabel independen. Hal ini ditunjukkan oleh nilai residual dalam regresi. Kriterianya jika nilai residual kecil atau nol maka terdapat kecocokan antara variabel independen dengan variabel moderating, sebaliknya jika nilai residual besar maka terjadi ketidak cocokan antara variabel independen dengan variabel moderating. Selain itu uji ini juga untuk menguji variabel moderating dalam hubungannya antara variabel dependen dan variabel independen lainnya.

persamaan uji residual ini mengambarkan apakah variabel etika auditor yang merupakan variabel moderating, ditunjukkan dengan nilai keofisien b6 kualitas audit. Apabila koefisien b3 negatif dan signifikan maka variabel etika auditor yang merupakan variabel moderating, yang memoderasi pengaruh variabel Kompetensi, Independensi terhadap hasil audit, sebaliknya jika variabel b3 hasilnya tidak negatif atau tidak signifikan maka variabel Etika auditor bukan variabel moderating.

\section{HASIL DAN PEMBAHASAN}

\section{Hasil Penelitian}

\section{Deskripsi Responden}

Ada pun jumlah responden yang menjadi objek penelitian ini adalah sebanyak 19 kantor akuntan publik yang ada dikota Medan, dimana dari total 19 kantor akuntan publik itu, terdapat 155 populasi jumlah auditor yang ada.

Maka dapat kita simpulkan bahwa sampel yang akan dipakai dalam penelitian ini adalah sebanyak 60 sampel auditor, ada pun kriteria sampel yang akan dipilih adalah responden yang telah mengembalikan kuesioner dan kantor akuntan yang memiliki lebih banyak auditor, karena kriteria itu mampu mewakili responden yang ada dan populasi yang ada, yang telah memberikan respon terhadap kuesioner ini, baik itu auditor junior, sampai kepada auditor senior. Dari total 19 kantor akuntan publik di kota medan, hanya 10 kantor akuntan publik yang memberikan responden dan yang telah mengembalikan kuesioner, yang lainnya tidak memberikan responden 
karena faktor-faktor internal baik itu kerahasian perusahaan dan tidak ketersediaan pihak perusahaan dalam keterbukaan untuk penilaian kinerja perusahaan dan auditor.

Dari hasil analisis deskriptif statistik bahwa range yang digunakan adalah skala likert 1 - 5 dimana nilai angka 1 menunjukkan sangat tidak setuju dan angka 5 menunjukkan sangat setuju. Ada pun penjelasannya adalah

1) Variabel kompetensi mempunyai nilai rata-rata 2.956 nilai rata-rata tersebut menunjukkan bahawa variabel kompetensi yang diambil sebagai sampel adalah baik. Dengan nilai minimum adalah 1.20 dan nilai maximum adalah 4.40 , sedangkan nilai standar deviasi adalah 1.084 yaitu menjauhi angka 0 sehingga dapat dikatan bahwa penyebarannya cukup beragam.

2) Variabel kompetensi mempunyai nilai rata-rata 2.970 nilai rata-rata tersebut menunjukkan bahawa variabel kompetensi yang diambil sebagai sampel adalah baik. Dengan nilai minimum adalah 1.00 dan nilai maximum adalah 4.60, sedangkan nilai standar deviasi adalah 1.110 yaitu menjauhi angka 0 sehingga dapat dikatan bahwa penyebarannya cukup beragam.

3) Variabel kompetensi mempunyai nilai rata-rata 3.058 nilai rata-rata tersebut menunjukkan bahawa variabel kompetensi yang diambil sebagai sampel adalah baik. Dengan nilai minimum adalah 1.40 dan nilai maximum adalah 4.60, sedangkan nilai standar deviasi adalah 1.117 yaitu menjauhi angka 0 sehingga dapat dikatan bahwa penyebarannya cukup beragam.

4) Variabel kompetensi mempunyai nilai rata-rata 2.911 nilai rata-rata tersebut menunjukkan bahawa variabel kompetensi yang diambil sebagai sampel adalah baik. Dengan nilai minimum adalah 1.20 dan nilai maximum adalah 4.60, sedangkan nilai standar deviasi adalah 1.064 yaitu menjauhi angka 0 sehingga dapat dikatan bahwa penyebarannya cukup beragam.

\section{Uji Reliabilitas}

Dengan menggunakan spss, maka kita dapat mengetahui apakah konsistensi jawaban para responden atas seluruh butir pertanyaan atau pernyataan yang digunakan. Ada pun tujuan dari pengujian reliabilitas untuk mengetahui apakah instrumen yang dalam hal ini kuesioner dapat digunakan lebih dari satu kali, paling tidak responden yang sama (umar, 2000). Dengan melakukan pengolahan data ke spss maka kita dapat melihat nilai keofisien Cronbach Alpha, jika nilai koefisien cronbach alphanya > 0,6 maka dapat dikatan instrumen tersebut reliabel. Maka untuk penelitian ini dapat dilihat pada tabel dibawah ini :

Tabel.1

Coefisien cronbach alpha

\begin{tabular}{lcc}
\hline Variabel & Nilai Cronbach Alpha & Batas reliabilitas \\
\hline Kompetensi & 954 & 0,6 \\
Independensi & 920 & 0,6 \\
Etika Auditor & 936 & 0,6 \\
Kualitas Audit & 903 & 0,6 \\
\hline
\end{tabular}

Dengan demikian dapat disimpulkan bahwa setiap instrumen dari kuesioner ini reliabel untuk dipakai lebih dari sekali dengan responden yang berbeda-beda, hal itu dapat kita lihat dari nilai coefisien cronbach alpha yang rata-rata diatas 0,6 .

\section{Uji Validitas}

Ada pun tujuan dari uji validitas untuk mengukur sah atau valid tidaknya suatu kuesioner, (Imam Ghozali : 2006). dengan demikian dapat di ringkas hasil pengujian validitas dapat 
disimpulkan bahwa semua item pertanyaan atau indikator yang ada, memiliki nilai diatas dari nilai $r$ tabel 0.250 , dapat diartikan bahwa semua variabel dapat digunakan untuk analisis selanjutnya.

\section{Pengujian Asumsi Klasik}

\section{Uji Normalitas}

Berdasarkan hasil uji normalitas data yang dilakukan dalam penelitian ini dengan menggunakan uji Kolmogorov-Smirnov dan dengan melihat uji grafik, maka dapat disimpulkan bahwa data mempunyai distribusi normal. Hal ini dapat diketahui dengan melihat nilai Kolmogorov Smirnov sebesar 0.860 dengan tingkat signifikansi sebesar 0.450. Jika signifikansi nilai Kolmogorov Smirnov lebih besar dari 0.05, maka dapat dinyatakan bahwa data mempunyai distribusi normal. Hal ini juga didukung dengan melihat grafik histogram, dimana data mengikuti garis diagonal, maka bisa daimbil kesimpulan bahwa, semua data yang dipakai berdistribusi normal, karena semmua titik-titik yang yang membentang pada garis diagonal tidak jauh letaknyanya dan selalu mendekat pada garis diagonal tersebut.

\section{Uji Heterokedastisitas}

Hasil dari pengujian heterokedastisitas, disimpulkan bahwa grafik scatterplos menunjukkan bahwa titik-titik yang ada dalam grafik tersebut, menunjukkan terjadi penyebaran secara acak serta dengan kata lain penyebarannya ada di atas maupun dibawah angka 0 pada sumbu Y. hal ini dapat disimpulkan bahwa dalam uji ini tidak terjadi heterokedastisitas pada model regresi ini.

\section{Uji Hipotesis}

Setelah dilakukan pengujian asumsi klasik dan diperoleh suatu kesimpulan bahwa model yang dihasilkan sudah dapat digunakan untuk melakukan pengujian ketahap selanjutnya yaitu analisa regresi berganda, adapun analisa regresi berganda dilakukan dengan melakukan pengujian hipotesis. Hal ini sesuai dengan rumusan masalah, tujuan masalah serta hipotesishipotesis yang disimpulkan pada bab II dalam penelitian ini, tujuan dari dilakukannya pengujian ini adalah untuk mrenghubungkan antara variabel dependen dengan beberapa variabel independen yang ada dalam satu model prediktif tunggal.

Dengan demikian model regresi linier berganda yang digunakan dalam penelitian ini, dapat disajikan sebagai berikut :

Model 1: $\quad Y=a+\beta 1 X 1+\beta 1 X 2+e$

Dimana :

$$
\begin{array}{ll}
\mathrm{a} & =\text { nilai interest konstan } \\
\mathrm{X} 1 & =\text { Kompetensi } \\
\mathrm{X} 2 & =\text { Independensi } \\
\mathrm{X} 3 & =\text { Etika Audit } \\
\mathrm{Y} & =\text { Kualitas Audit } \\
\mathrm{e} & =\text { erorr }
\end{array}
$$

Pengujian yang dilakukan pada variabel independen terhadap variabel dependen diuji pada taraf $5 \%$. Ada pun kriteria dalam pengambilan keputusan adalah melakukan penerimaan atau penolakan pada setiap hipotesis dengan membandingkan t hitung dengan $t$ table untuk masingmasing koefisien regresi yang dihgasilkan dalam pengujian analisis ini. Dengan kesimpulan sebagai berikut :

$\mathrm{HO}$ diterima : Apabila t hitung lebih kecil dari t tabel. 
H0 ditolak : : Apabila t hitung lebih besar dari t tabel.

\section{Analisis Regresi Linier Berganda}

Analisis statistik yang digunakan dalam penelitian ini yaitu analisa regresi linier berganda. Adapun fungsi analisis ini untuk mengetahui besarnya pengaruh variabel-variabel bebas (independen) yaitu kompetensi, independensi dan etika auditor terhadap variabel variabel terikat (dependen) yaitu kualitas audit. Berdasarkan hasil analisis maka diperolehlah regresi sebagai berikut :

Tabel. 3

Uji Regresi Berganda

Coefficients ${ }^{a}$

\begin{tabular}{lccccc}
\hline \multirow{2}{*}{ Model } & \multicolumn{2}{c}{$\begin{array}{c}\text { Unstandardized } \\
\text { Coefficients }\end{array}$} & $\begin{array}{c}\text { Standardized } \\
\text { Coefficients }\end{array}$ & \multirow{2}{*}{ T } & Sig. \\
\cline { 2 - 4 } & $\mathrm{B}$ & Std. Error & Beta & & \\
\hline 1 (Constant) & .472 & .302 & & 1.565 & .123 \\
Kompetensi & .710 & .101 & .690 & 7.008 & .000 \\
Independensi & .498 & .126 & .495 & 3.951 & .000 \\
Etika_Auditor & -.341 & .143 & -.325 & -2.392 & .020 \\
\hline
\end{tabular}

a. Dependent Variable: kualitas_audit

Sumber : data primer diolah

Berdasarkan tabel diatas maka persamaan regresi yang terbentuk pada uji regresi adalah : $Y=0,472+0,710 X_{1}+0,498 X_{2}+e$

Model ini dapat diinterprestasikan sebagai berikut :

a. Adapun koefisisen variabel $\mathrm{X}_{1}$ (Kompetensi) diperoleh sebesar 0,710 dengan arah koefisien positif. Hal ini menunjukkan bahwa kompetensi yang baik akan menghasilkan kualitas audit yang baik juga dalam pemeriksaan laporan keuangan.

b. Adapu koefisien variabel $X_{2}$ (independensi) diperoleh sebesar 0,498 dengan arah koefisien positif. Hal ini menunjukkan bahwa semakin Independen seorang auditor maka akan menghasilkan kualitas audit yang baik juga dalam pemeriksaan laporan keuangan.

\section{Pembahasan}

\section{Pengaruh Kompetensi terhadap kualitas audit}

Berdasarkan hasil alat analisis yang dipakai, maka dapat diambil kesimpulan bahwa kompetensi, Independensi berpengaruh secara siginifikan terhadap kualitas audit demikian juga terhadap etika auditor yang menjadi varibel moderating. Dengan demikian dapat dijelaskan, yaitu Hasil penelitian ini dapat dilihat pada uji t di tabel 4.6 dengan kesimpulan sebagai berikut adanya pengaruh yang positif dari variabel kompetensi maka dengan demikian dapat diartikan bahwa semakin tinggi atau semakin kuat kompetensi yang dimiliki oleh seorang auditor maka dengan demikian dapat diartikan bahwa dalam melakukan audit maka hasil yang diperoleh dari kualitas audit dalam laporan keuangan akan lebih baik juga dan akurat.

Hasil penelitian ini mendukung hasi hipotesis pertama yang mana Kompetensi 
berpengaruh signifikan terhadap kualitas audit, hasil penelitian ini juga mendukung hasil penelitian yang dilakukan oleh Christiawan (2002) dan Alim, dkk (2007) diman dari hasil penelitiannya bahwa kompetensi berpengaruh signifikan terhadap kualitas audit.

\section{Pengaruh Independensi terhadap kualitas audit}

Dari hasil analisis dengan mengunakan uji t pada tabel 4.6 diatas maka dapat disimpulkan bahwa Independensi berpengaruh secara positif dan signifikan terhadap kualitas audit. Sehingga dapat diakatankan bahwa ketika seorang auditor memiliki prinsip independen dalam menjalankan tugasnya maka, akan lebih menjamin kualitas audit yang dihasilkan lebih independen atau dapat dipercaya. Penelitian ini didukung dengan penelitian terdahulu yaitu Lavin (1976) dalam Alim (2007) menjelaskan banyaknya penelitian mengenai independensi menunjukkan bahwa faktor independensi merupakan faktor penting bagi auditor untuk menjalankan profesinya, Arens dkk (2004) menyatakan bahwa nialai auditing sangat tergantung pada persepsi publik akan independensi yang dimiliki oleh auditor. Sikap independen meliputi independen dalam fakta (in fact) dan independen dalam penampilan (in appearance). Demikian juga Christawan (2002) dan Alimm dkk (2007) dari penelitian ini diketahui bahwa independensi auditor berpengaruh terhadapa kualitas audit.

\section{Pengaruh Kompetensi, Independensi terhadap kualitas audit.}

Dengan mengunakan uji $f$ dengan melihat tabel 4.4 maka didapatkan hasil sebagai berikut bahwa kompetensi dan independensi secara bersama-sama berpengaruh signifikan terhadap kualitas audit. Sehingga dapat dikatan bahwa kompetensi dan Independensi seorang auditor sangat penting demi menjaga hasil kualitas audit yang dihasilkan dalam melakukan audit laporan keuangan. Penelitian ini juga didukung leh penelitian sebelumnya yang dilakukan oleh Deis dan Giroux (1992) dalam Alim (2007) kemampuan seorang auditor dalam melakukan tugasnya sangat tergantung kepada sikap etika profesionalnya.

\section{Etika Auditor Memoderasi hubungan Kompetensi terhadap Kualitas Audit}

Dengan mengunakan uji moderating, dan memakai alat analisis uji residual maka dapat disimpulkan bahwa etika auditor bukanlah variabel moderating dimana variabel yang mampu mempengaruhi hubungan kompetensi terhadap Kualitas audit baik itu dalam hal memperkuat dan memperlemah. Dengan demikian dapat dikatakan bahwa etika auditor bukanlah salah satu unsur penting dalam prinsip pengauditan dalam menghasilkan laporan keuangan yang berkualitas. Penelitian ini didukung juga dengan hasil penelitian yang dilakukan oleh kitta (2009 bahwa idealisme orientasi etika auditor tidak menguatkan atau melemahkan hubungan antara kompetensi dengan kualitas audit.

\section{Etika Auditor Memoderasi hubungan Independensi terhadap Kualitas Audit}

Pada tabel 3 maka dapat disimpulkan bahwa etika auditor bukanlah variabel moderating, 
yang dimana variabel tersebut mampu mempengaruhi hubungan suatu variabel yang satu dengan variabel yang lain dalam penelitian ini variabel $X 1$ kompetensi terhadap variabel $Y$ yaitu kualitas audit. Dengan demikian dapat disimpulkan bahwa etika auditor bukanlah satu unsur penting dalam prinsip pengauditan terhadap laporan keuangan dan etika auditor tidak mempengaruhi kualitas audit yang dihasilkan pada laporan keuangan.

Penelitian ini didukung juga dengan hasil penelitian yang dilakukan oleh Alim, dkk (2007) yang meneliti tentang pengaruh kompetensi dan independensi terhadap kualitas audit yang dimana etika auditor sebagai variabel moderating, dengan hasil kompetensi berpengaruh terhadap kualitas audit, sedangkan interaksi kompetensi dan etika auditor tidak berpengaruh signifikan terhadap kualitas audit.

\section{REKOMENDASI KEBIJAKAN}

\section{Rekomendasi}

Berdasarkan dari hasil analisis dan uji hipotesis yang dilakukan dan menghasilkan diambil kesimpulan, yaitu bahwa Kompetensi berpengaruh positif terhadap kualitas audit, sehingga dapat dikatan bahwa seorang auditor semakin memiliki kompetensi yang tinggi maka tingkat kualitas dari laporan keuangan yang dia audit akan semakin berkualitas, kedua; Bahwa Independensi berpengaruh postif terhadapa kualitas audit, sehingga bisa dapat dikatan bahwa seorang auditor semakin independen dalam menjalan tugasnya, maka hasil audit dari laporan keuangan yang dihasilkan akan semakin dapat dipercaya. Ketiga, bahwa Kompetensi dan Independensi berpengaruh positif secara bersama-sama terhadap kualitas audit, maka dapat dikatan bahwa kedua unsur ini sangat penting untuk seorang auditor dalam menjalankan tugas dalam mengaudit laporan keuangan agar mendapatkan kualitas audit yang baik dan dapat dipercaya. Keempat, Bahwa Etika Auditor tidak mempengaruhi baik itu memperlemah atau memperkuat antara kompetensi terhadapa kualitas audit, maka dengan ini dapat dikatan bahwa etika auditor bukanlah salah satu hal prinsip yang dimiliki oleh seorang auditor yang mampu menganggu prinsip kompetensi dan independensi terhadap kualitas audit. Dan kelima; Bahwa etika auditor bukanlah variabel yang mampu memperkuat dan memperlemah independensi terhadap kualitas audit

\section{Kebijakan}

Bedasarkan hasil dan interpretasi penelitian ini, maka peneliti memberikan saran sebagai rekomendasi kebijakan antara lain :

1) Penelitian ini tidak melibatkan seluruh Kantor Akuntan Publik yang ada di kota Medan karena ketidak jelasan alamat dan adanya larangan dari pihak kantor akuntan publik untuk mengisi kuesioner.

2) Penelitian ini dilakukan dengan cara kuesioner, dimana pengisiin kuesioner yang dilakukan oleh pihak auditor kadang-kadang tidak cermat atau tidak teliti, sehingga dari sisi ini menjadi kelemahan dalam penelitian ini.

\section{DAFTAR PUSTAKA}

Abdolmohammadi, Mohammad and Arnold Wright (1987). An Ex, Journal of the effects of Experience and Task Complexity on Audit Judgements, The Accounting Review. (January), 
$1-13$.

Arens. Alvin a., Elder . Randal J dan Beasly. Marks S (2001). Auditing dan pelayanan Verifikasi . PT. Intermasa.

Aldhizer, George R., dan James D. Cashell. 1996. Internal Auditor Outsourcing, The CPA Journal (October), 40-52.

James C. Lampe. 1997. Competitive Bidding, Auditor Tenure, and the Extent of single Audit Findings, The Accounting Review (April), 218-239.

Ashton, Alison Hubbard. 1991. Experience and Error Frequency Knowledge as Potential Determinants of Audit Expertise, The Accounting Review (April), 218-239.

Austin, Kenneth R. dan David C. Langston. 1981. Peer Review; Its Impact on Quality Control" Journal of Accountancy, 24, 99-108.

Bonner, Sarah E. 1990. Experience Effects in Auditing: The Role of Task-Specific Knowledge, The Accounting Horizons (Maret), 7-24.

Bremser, Wayne G. 1983. Peer Review: Enhancing Quality Control, Journal of Accountancy (Oktober), 78-88.

Choo, Freddie dan Ken T.Trotman. 1991. The Relationship Between Knowledge Structure and Judgements for Experienced and Inexprienced Auditors. The Accounting Review (Juli), 464-485.

Deis, Donald R., dan Gary A.Giroux. 1992 Determinants of Audit Quality in the Public Sector, The Accounting Review (July), 462-479.

Fogarty, Timothy J. 1996. The Imagery and Reality of Peer Review in the US: Insights from Institutional Theory, Accounting, Organizations, and Society, 21, 243-267.

Holmes, W. Athur dan Burns , C. David (1996 ). Auditing Norma dan Prosedur. Jakarta. Penerbit Erlangga.

Hogan, Chris E. 1997. Cost and benefits of Audit Quality in IPO Market: A Self-Selection Analysis, The Accounting Review (January), 67-86.

Hogarth, Robin M. 1991. A Perspective on Cognitive Research in Accounting, The Accounting Review(April), 277-290.

Malone, Charles F. dan Robin W. Roberts. 1996. Factors Associated with the Incidence of Reduced Audit Quality Behaviours, Auditings ,15 (Fall), 49.

McDaniel, Michael A., John E. Hunter, dan Frank L. Schmidt. Job Experience Correlates of Job Performance, Journal of Applied Psychology, 327-330.

Pany, Kurt dan Philip M.J. Reckers. 1980. The Effect of Gifts, Discounts, and Client Size on Perceived Auditor Experience, The Accounting Review (Januari), 50-61.

Rahayu, Kurnia Siti dan Suhayati Ely. 2010. Auditing, Konsep Dasar dan Pedoman Pemeriksa Akuntan Publik.Graha IImu. Yogyakarta

Shockley, Radolph. 1981. "Perceptions of Auditors Indipendence: An Empirical Anlysis. The Accounting Review (Oktober), 785-800.

Supriyono, R.A. 1998. Pemeriksaan Akuntan; Faktor-faktor yang Mempengaruhi Indipendensi Penampilan Akuntan Publik, Edisi Pertama, BPFE.

Sutton, Steve G. 1993. Toward an Understanding of the Factors Affecting the Quality of the Audit Process, Decision Sciences, 24, 88-105.

Teoh, Siew Hong dan T.J. Wong. 1993. Perceived Auditor Quality and the Earnings Response Coefficient, The Accounting Review (April), 346-366.

Tubbs, Richard M. 1992. The Effect of Experience on the Auditor's Organization and Amount of Knowledge, The Accounting Review (Oktober), 783-801. 